\title{
Chapter 12 \\ Responding to Superdiversity Whilst \\ Upholding Te Tiriti $O$ Waitangi: \\ Challenges for Early Childhood Teacher \\ Education in Aotearoa New Zealand
}

\section{Angel Chan and Jenny Ritchie}

\begin{abstract}
Countries with a superdiverse population due to increases in migration have been slow in recognising and addressing social inequalities driven by this situation (Vertovec, 2007). In Aotearoa (New Zealand), there are now more than 200 different ethnic groups and $27.4 \%$ of its population was born overseas (Statistics New Zealand, 2019), and there is also an increasing number of students with diverse cultural, linguistic and migration backgrounds enrolled in the country's early childhood teacher education programmes. The manifestation of superdiversity in Aotearoa is particularly complex and challenging since it occurs within a legislated 'bicultural' context (Royal Society of New Zealand, 2013). In light of these concerns, this paper reports findings from a study which utilised a methodology of critical discourse analysis (Gee, 2011; Jørgensen \& Phillips, 2002) to examine several key institutional policy documents in order to interrogate the responsibilities of early childhood teacher education in supporting both the country's commitment to 'biculturalism' and its current superdiverse demographics. The theoretical analysis draws on Vertovec's (2007) superdiversity approach, critical multiculturalism (May, 1999) and critical and Indigenous pedagogies of place (Penetito, 2009; Perumal, 2015). While all the documents make explicit references to 'bicultural' commitments, minimal attention is given to migration-related inequality issues. Our analysis highlighted complex inter-relationships and tensions between honouring 'biculturalism' and catering for superdiversity. Recognising and addressing this complexity is important in future policy development, and teacher education providers need to ensure that their graduates have the knowledge and skills to work equitably with children, families and communities in order to address inequalities emanating from the history of colonisation in Aotearoa as well as the current superdiversity situation.
\end{abstract}

\footnotetext{
A. Chan $(\varangle)$

The University of Auckland, Auckland, New Zealand

e-mail: angel.chan@auckland.ac.nz

J. Ritchie

Te Herenga Waka Victoria University of Wellington, Wellington, New Zealand

e-mail: jenny.ritchie@vuw.ac.nz 


\section{Introduction}

Increased mobility of populations globally generates challenges for education systems in responding to demographic complexities such as the recent phenomenon of superdiversity (Vertovec, 2007, 2019), and in Aotearoa (New Zealand), these challenges and complexities have to be considered within the local 'bicultural' ${ }^{1}$ legislative context. This chapter offers a critical discourse analysis (CDA) of key policy documents with regard to superdiversity and 'biculturalism' in early childhood (EC) teacher education in Aotearoa. Teacher education programmes in Aotearoa are increasingly enrolling students who have diverse ethnic, cultural, linguistic and migration backgrounds. This chapter aims to interrogate the roles and responsibilities of initial and in-service EC teacher education with regard to addressing issues of identity, equity and social justice in light of the changing demographic landscape in Aotearoa, a country that has a history of colonisation and is also now considered 'superdiverse' (Royal Society of New Zealand, 2013). Previous research has highlighted challenges for teacher education in relation to honouring a commitment to Te Tiriti o Waitangi (Ritchie, 2002), and subsequent Education Review Office ${ }^{2}$ (ERO) reports have expressed concerns regarding the ongoing challenges faced by the early childhood education (ECE) sector in this regard (ERO, 2010, 2012, 2013). It has been pointed out that policies and practices in many countries with a large population of diverse migrants have yet to adequately respond to the more recent superdiversity phenomenon (Vertovec, 2007). Similar concerns were raised by a recent study in Aotearoa (Chan, 2019a) which examined how the revised national EC curriculum Te Whāriki (Ministry of Education, 2017) addresses issues emerging from the nation's current superdiversity situation. This chapter utilises a range of theoretical approaches and a methodology of CDA to examine several key policy documents and consider the implications for initial and in-service EC teacher education of increasing superdiversity in a country which is yet to reconcile its history and ongoing legacy of the colonisation of the Indigenous Māori, despite the 1840 treaty commitments that had led Māori to believe that their authority would be respected (Spoonley, 2017; Walker, 2004). From this perspective, the chapter reviews and contests changes and challenges emerging in the field of EC teacher education in relation to globalisation, internationalisation and local contextual issues.

\footnotetext{
${ }^{1}$ We choose to problematise the terms 'bicultural' and 'biculturalism'. Although they derive from recognition of the two original parties to the 1840 Tiriti o Waitangi, the Indigenous Māori and the British Crown, subsequent migration policies have resulted in a greater diversity of ethnicities and languages.

${ }^{2}$ The Education Review Office is the government department that regularly evaluates individual ECE services and schools, and also publishes national reports on specific issues.
} 


\section{Historical Context}

As Freire (1972) wisely informed us, education is neither politically neutral nor ahistorical. Early childhood teacher education is no exception. In order to appreciate the educational implications of the current situation of superdiversity in Aotearoa, it is important to understand these within the particular historical context of comparatively recent British colonisation. Māori are estimated to have arrived in Aotearoa from the South Pacific around 1300CE (King, 2003). After various early encounters between Māori and European explorers, sealers and whalers (Salmond, 1991), the first British missionaries arrived in 1814. The 1835 affirmation of New Zealand as a Māori sovereign nation in He Whakaputanga o te Rangatiratanga o $\mathrm{Nu}$ Tireni I Declaration of Independence of the United Tribes of New Zealand preceded the 1840 signing of Te Tiriti o Waitangi ${ }^{3}$ between the British Crown and Māori chiefs (Orange, 1988; Walker, 2004). The latter treaty, whilst allowing for British settlement, also gave important undertakings to Māori: recognition that they would retain their tribal selfdetermination over their lands, villages and everything of value to them, including their language; that they would be equal citizens to the British; and that their belief systems would also have equal status to the religions of the British and French missionaries present at the treaty signing (Orange, 1988).

Despite the clearly worded articles of Te Tiriti o Waitangi, the British Crown chose to assume the rights of sovereignty, as stated in the English language version of the treaty, the Treaty of Waitangi, which was not the same as the kawanatanga (governance) ceded by Māori in the original Tiriti document signed by the vast majority of Māori chiefs. ${ }^{4}$ The 1852 New Zealand Constitution Act resulted in the establishment of a British settler government that ignored its Te Tiriti o Waitangi obligations, and excluded the voices and rights of Māori. The government thereafter passed innumerable laws and policies which served to alienate Māori from their lands, language, traditions and cultural identities (Orange, 1988; Walker, 2004). Māori were thus denied basic human rights that were available to the settlers, such as access to education in their own language and to higher levels of education, through wide-scale state-imposed policies and practices of disenfranchisement and discrimination. Ongoing Māori activism resulted in the treaty finally, after 135 years, being recognised in legislation in the Treaty of Waitangi Act (1975) which established the Waitangi Tribunal to consider treaty breaches. However, the long-term legacy of this systemic discrimination is that Māori continue to be negatively represented in social statistics including those related to educational achievement, poverty, imprisonment and youth suicide (Radio New Zealand (RNZ), 2019a).

Whilst the legitimate expectations of Māori, based in treaty assurances, were largely ignored by the colonisers, Māori have consistently sought to have these upheld (Walker, 2004). Slowly over the past three decades, substantive Māori grievances

\footnotetext{
${ }^{3}$ Te Tiriti o Waitangi refers to the original treaty written and signed in te reo Māori, the Māori language.

${ }^{4}$ Te Tiriti o Waitangi, the Māori text, was signed by over 500 chiefs, and the English version by only 39 (Orange, 2017).
} 
have received official recognition albeit with token compensation by successive governments. One aspect of this recognition is an ostensible policy of 'biculturalism' which purports to give equal status to Māori but which has been criticised in that governments have largely continued to fail to share power, resources and decisionmaking with Māori (Walker, 2004). Languages encapsulate cultural beliefs and knowledge systems. It could, therefore, be assumed that bilingualism (both English and te reo Māori, the Māori language) should feature strongly in a 'bicultural' policy. This has not been the case in Aotearoa. The Māori language was belatedly recognised in 1987 as the official language (New Zealand Parliament, 1987). Whilst "Maori communities have over a long period made claims to the establishment to include their language, knowledge, history and practices into the curriculum" (Penetito, 2002, p. 98), the number of speakers of te reo Māori remains low. Only $11 \%$ of Māori report that they can speak te reo very well or well, but $45 \%$ are unable to speak anything beyond a few words or phrases (Ministry of Social Development, 2016).

A further serious critique of the policy of 'biculturalism' is that it fails to adequately recognise Māori as the first nations peoples of this land. Retired High Court Judge and former Chair of the Waitangi Tribunal Sir Eddie Taihakurei Durie has offered an inclusive Tiriti-based paradigm which both affirms Māori as tangata whenua (people of this land) and, in addition, considers all those who have migrated subsequently to be 'tangata tiriti', people who live in this land "by right of Te Tiriti o Waitangi" (Turia, 2016, p. 36). The latter includes all those who reside in Aotearoa due to Te Tiriti having allowed initial British settlement followed by subsequent migration under kawanatanga I government policies. These policies were for many years covertly racist, favouring 'Whites only' (Brawley, 1993). Policy changes post World War II brought a huge increase of 'non-white' migrants, firstly from various Pacific nations, and since the 1987 Immigration Act, predominately from Asia (Spoonley \& Bedford, 2012).

\section{Current Demographic Context}

The population landscape of Aotearoa has transformed significantly over the years. The most recent census revealed that $27.4 \%$ of respondents were not born in New Zealand, whilst Māori currently represent $16.5 \%$ of the overall population (Statistics New Zealand, 2019). ${ }^{5}$ An even more seismic demographic shift can be seen in the relative proportions of ethnic groups represented in ECE enrolments, whereby those of Pākehā I European ancestry now account for only 48.21\%, Māori 23.72\%, and the remainder comprising a diverse range of ethnicities (Education Counts, 2018). A similar increased diversity is evident in statistics on the ethnicity of EC teachers in that "Māori teaching staff accounted for $9.0 \%$ of all teaching staff [and] Asian teaching

\footnotetext{
${ }^{5}$ There were demonstrable difficulties related to a low response rate with the first ever e-census, conducted in 2018, the implications of which are acknowledged as being particularly concerning for Māori and raise issues of Indigenous data sovereignty (Kukutai \& Cormack, 2018).
} 
staff now make up $11.5 \%$ of all teaching staff in teacher-led services" (Education Counts, 2014, p. 9).

Immigration New Zealand (2019) now lists EC teachers in the 'skill shortage' category with regard to eligibility for a residency visa. At the same time, universities in Aotearoa continue to market their programmes to international students, increasing the enrolments of such students in EC teacher education programmes. These situations have implications for Aotearoa's EC teacher education in terms of the nation's commitment to social justice, equity and Tiriti-based ${ }^{6}$ (rather than 'bicultural') policy and practice, along with our responses to superdiversity. In a Tiriti-based paradigm, Māori are recognised as having the right of tino rangatiranga (self-determination) as tangata whenua, and te ao Māori (the Māori world) as expressed through te reo Māori is given prominent recognition. This paradigm also acknowledges the increasing diversity of tangata tiriti, all those whose ancestry is other than Māori.

\section{Theoretical Positioning}

We draw upon a range of theoretical and conceptual frameworks including Steven Vertovec's (2007) superdiversity approach; critical multiculturalism (May, 1999; May \& Sleeter, 2010) and critical and Indigenous pedagogies of place (Penetito, 2009; Perumal, 2015; Williams, Bunda, Claxton, \& MacKinnon, 2018) to analyse relevant discourses promoted in several key institutional documents. These frameworks are used to highlight inequalities and social justice issues in EC teacher education in order to facilitate transformation of policies and pedagogies with the intentions to both foster connectedness with local Māori histories and mātauranga (knowledge) and cater to superdiversity complexities.

Since its inception more than a decade ago, the term 'superdiversity' has been applied in studies across multiple disciplines including early childhood education (Chan, 2019a, 2019b); migration (Spoonley, 2015); social inequality (Aptekar, 2019) and language (Blommaert, 2013). This approach goes beyond examining conventional diversity issues in relation to ethnicity, culture and language. Instead, it highlights the interactivity of complexities generated from contemporary migration situations, focusing in particular on social inequality issues driven by migration. ${ }^{7}$ It responds to "the search for better ways to describe and analyse new social patterns, forms and identities arising from migration-driven diversification" (Vertovec, 2019, p. 125), and highlights the need to transform policies and practices to cater for superdiverse demographics.

\footnotetext{
${ }^{6}$ We use the term 'Tiriti o Waitangi based' (or more simply Tiriti based) instead of 'bicultural' to recognise the first nations status of Māori and the obligations that government, and by extension, teachers have under Te Tiriti o Waitangi to recognise Māori self-determination over their lands, language, knowledges and resources.

${ }^{7}$ For example, recent reports have highlighted the need to recognise health issues (Tolley, 2019) and exploitation of migrants (Hickey \& Grieveson, 2019) in Aotearoa.
} 
Contemporary migrants are extremely diverse and highly mobile. They are diverse not only in ethnicity, culture and language; but also in terms of their migration patterns and statuses, which are two key considerations in the superdiversity approach (Vertovec, 2007, 2019). Differing patterns (for example, permanent settlement in the host countries or transnational migration which involves ongoing commuting activities between the home and host countries) and statuses (for example, voluntary skilled and investment migrants or involuntary migrants with a refugee background) mean contemporary migrants are more heterogeneous than ever before. This heterogeneity means that migrants may not all have the same rights and resources. Voluntary transnational migrants, for example, may have the opportunities to benefit from resources offered in the home and host countries, but because their time is divided across two countries, they may struggle to develop a sense of belonging and identity in the host country (Chan, 2018; Chan \& Spoonley, 2017). Some host country locals may perceive this group of migrants to be disloyal and destabilising of national identity and collective heritage, and therefore marginalise and exclude them (Goldberg, 2002).

The notions of transformation and heterogeneity are also emphasised in critical multicultural studies. Critical multicultural scholars have long argued that it is unjust to homogenise any cultural or ethnic group and that it is inequitable to assume that members of each group have similar needs and to therefore provide only static and standardised supports (May, 1999). A recent study (Chan, 2019b) connected key ideas of the superdiversity approach and critical multicultural theorising, suggesting the cross-application of these to transform policies and practices to be responsive to migration-related inequality issues in ECE. In light of the migration patterns and statuses emphasised in a superdiversity approach, the complex layers of migrationrelated inequalities must be taken into consideration along with recognition of the rights and histories of tangata whenua when reviewing and enacting institutional policies such as those mandated by the New Zealand Teaching Council. ${ }^{8}$

As the severity of the current climate and biodiversity extinction crisis becomes increasingly evidenced (Stockholm Resilience Centre, 2019; United Nations, 2019), recognition of the connections between histories of colonisation and environmental degradation leads us to consider the necessity for teacher education programmes to include a focus on critical and Indigenous pedagogies of place (Chan \& Ritchie, 2019). Such pedagogies recognise the historical, political, economic, cultural and social contexts that underpin the place-based locatedness of educational work in order to take a decolonising approach that validates local Indigenous traditional ecological knowledges (Penetito, 2009; Perumal, 2015; Williams et al., 2018). The United Nations Sustainable Development Goals for 2030 require education systems to equip children with the knowledges and skills to enable them to contribute to the "transformation of human-social structures towards the goal of social-ecological

\footnotetext{
${ }^{8}$ The current title for the body that oversees the teaching profession and initial teacher education programme approvals in Aotearoa is 'Teaching Council New Zealand I Matatū Aotearoa'. Originally the Teacher Registration Board (as per the 1989 Education Act), from 2002 it was called the 'Teachers Council' and from 2014 to September 2018, it was entitled the 'Education Council I Matatū Aotearoa'.
} 
resilience" (Williams et al., 2018, p. 50). The repertoires of Māori traditional wisdom along with those of migrant children and families can contribute to such work, drawing upon families' ancestral funds of knowledge (Gonzalez, 2005) regarding ways of living sustainably and caring for Aotearoa collectively. In applying critical and Indigenous pedagogies of place, EC teachers can support migrant children and families to understand the histories of the host country and Māori traditional knowledges, and to develop a sense of connection and belonging to Aotearoa.

\section{Critical Discourse Analysis (CDA) as an Analytical Tool}

Methodologically, we utilise a critical discourse analysis (Gee, 2011; Jørgensen \& Phillips, 2002; Locke, 2004) of several key documents to identify dominant discourses influencing EC teacher education in Aotearoa and to also consider discourses which may be silenced and/or marginalised. Discourses are socio-historically constructed, determining the salient knowledge and arranging the social order (Gee, 2011). Dominant and institutional discourses are naturalised over time to become taken-for-granted and 'common-sense' knowledge (Gee, 2011; Locke, 2004). Policy documents mandated by the Ministry of Education and the Teaching Council through the promotion of particular discourses influence and regulate teacher education in Aotearoa. If these discourses are not challenged through thoughtful examination, they have the potential to become ingrained beliefs and practices that are uncritically performed by practitioners. The power of such normative discourses is such that "subscribers of non-powerful discourses are therefore marginalised and relatively disempowered" (Locke, 2004, p. 37). Rendering the norms and hierarchies of discourses visible is important when reviewing documents and policies in order to disrupt power relations, and to transform policies and practices so that they become inclusive of diverse discourses (Locke, 2004). The purpose of CDA is

to provide opportunities for critical detachment and review of the ways in which discourses act to pervade and construct our textual and social practices in a range of contexts. (Locke, 2004, p. 89)

Discourses promoted and mandated by institutions usually reflect the social and political contexts within which they were created. This study therefore considers whether current key EC and teacher education documents are reflective of not only ongoing commitments to tangata whenua but also responsive to current superdiverse demographics.

Language and other linguistic expressions can also be interrogated using a CDA approach to identify underlying discourses in narratives (Gee, 2011; Locke, 2004). We utilised the work of Jørgensen and Phillips (2002) whose take on CDA as both theory and methodology builds on the work of Ernesto Laclau and Chantal Mouffe, as well as of Norman Fairclough. This approach recognises that identities are "discursively constituted through chains of equivalence where signs [also termed 'key signifiers'] are sorted and linked together in chains in opposition to other chains 
which thus define how the subject is, and how it is not" (Jørgensen \& Phillips, 2002, p. 45). We thus identified 'key signifiers' from selected texts, which as contextualised within 'chains of equivalence' (phrases which indicate shared meanings), "are combined with other signs that fill them with meaning" (Jørgensen \& Phillips, 2002, p. 50). These key signifiers (in this paper, we use key statements from the documents) are then examined in relation to their historicity and with consideration as to how entities such as discourses and identities "are always established relationally, in relation to something they are not" within shared social spaces (p. 50). This framing has relevance to complexities of tangata whenua I tangata Tiriti and superdiversity dynamics in Aotearoa and to the potential of applying critical and Indigenous placebased pedagogies to address the possible polarisations, and prevent the perpetuation of social, cultural and ecological injustices.

\section{Findings and Discussion}

In order to understand the discursive context of EC teacher education pertaining to Te Tiriti o Waitangi in relation to both tangata whenua and tangata tiriti, including the current superdiversity situation, we began our analysis by considering key statements across three highly influential documents:

1. Te Whāriki. He whāriki mātauranga mō ngā mokopuna o Aotearoa (Ministry of Education [MoE], 2017), hereafter Te Whāriki 2017;

2. Our code, our standards: Code of professional responsibility and standards for the teaching profession ${ }^{9}$ (Education Council, 2017a), hereafter Code and Standards; and

3. He taonga te tamaiti. Every child a taonga. Early learning action plan 2019-2029 (MoE, 2019), hereafter Early Learning Action Plan.

These documents were chosen as representative of key discourses that emanate from the Ministry of Education and the Teaching Council, and which have direct bearing on EC teacher education programmes in their preparation of future teachers. The first two documents are the mandated EC curriculum and the Code and Standards which are required to be demonstrated by all graduating and registered teachers. The third document, the Early Learning Action Plan, is the recently released Ministry of Education strategic plan for the entire ECE sector.

\footnotetext{
${ }^{9}$ This document sets out a list of code of professional responsibility and standards for the teaching profession. The code and standards are required to be used by all teacher education providers to ensure that their student-teachers work towards them during their study and by the Teaching Council in overseeing applicants' suitability to be granted teacher registration. We also make reference to a fourth document from the Teaching I Education Council (2017b) which provides 'Examples in practice' as a companion document to the Code and Standards.
} 


\subsection{Commitment Statements: Te Tiriti O Waitangi}

In this section, we have created a table by selecting segments from each of the key statements prominently positioned at the start of each of the three key documents that outline commitments required of teachers in relation to Te Tiriti o Waitangi. We have highlighted in bold key signifiers for analysis and discussion that follows.

\subsubsection{Analysis and Discussion: Inter-Relationships and Tensions}

We now draw from some of the key signifiers ${ }^{10}$ identified in Table 12.1 to analyse the implications employed within the three key documents. We then go on to discuss some of the tensions that arise from this analysis. Both the Ministry's Early Learning Action Plan and the Teaching Council's Code and Standards reference only Te Tiriti o Waitangi, the original treaty written in te reo Māori. Upholding the mana of Te Tiriti o Waitangi is important, as it contains specific undertakings to Māori that are not mentioned in the English language version, specifically in Article Two te tino rangatiratanga [absolute authority] over whenua, kainga and taonga katoa [lands, villages and everything of value] and in Article Three, ngā tikanga katoa rite tahi... [equal rights] (Orange, 2017). Notably, the Early Learning Action Plan is the only document to expressly recognise tino rangatiratanga as affirmed in Article Two of Te Tiriti, literally the absolute authority of the chiefs, often translated as Māori self-determination. However, in Te Whäriki 2017, reference is made to both versions of the treaty: Te Tiriti o Waitangi and the English language Treaty of Waitangi. To regard the two (significantly different) texts as having equal status has been the official government position since 1975, ignoring the fact that the Māori text was signed by a much larger number of Māori chiefs (see footnote \#4) and contains the significant affirmation of tino rangatiratanga.

In its reference to 'partnership, participation and protection', Te Whäriki 2017 perpetuates a discourse commonly referred to as the 'three'p's', and this was a simplistic interpretation of treaty 'principles'. This trope has had ongoing traction, perhaps because it allows users to ignore the significance of the specific commitments in the Tiriti articles as outlined above. It also ignores the significant body of work from the Courts and Waitangi Tribunal which has catalogued a complex array of principles emergent over subsequent years (Hayward, 2004). Whilst Te Whäriki 2017 and the Code and Standards make specific reference to im/migrants in outlining Tiriti obligations, the Early Learning Plan does not do so, referring several pages later to increasing ethnic diversity but not in relation to tangata whenua I tangata tiriti relationships. Only the Code and Standards makes explicit reference to addressing the injustices caused by colonisation and states that both previous and new settlers should respect the commitments in Te Tiriti.

Our discussion now considers some of the inter-relationships and tensions involved in the obligations for teachers regarding the currently mandated Tiriti o

${ }^{10}$ Unfortunately space prevents us from pursuing a more in-depth analysis of the key signifiers. 
Table 12.1 Te Tiriti o Waitangi statements: identifying key signifiers

\begin{tabular}{|c|c|c|}
\hline Te Whāriki 2017 (p. 3) & Early learning action plan & Code and standards (p. 4) \\
\hline $\begin{array}{l}\text { Te Tiriti o Waitangi I the } \\
\text { Treaty of Waitangi is New } \\
\text { Zealand's founding document }\end{array}$ & $\begin{array}{l}\text { The Government is } \\
\text { committed to honouring the } \\
\text { Crown's commitments } \\
\text { arising from Te Tiriti o } \\
\text { Waitangi (p. } 8 \text { ) }\end{array}$ & $\begin{array}{l}\text { Te Tiriti o Waitangi } \\
\text { affirmed Māori rights as } \\
\text { tangata whenua and } \\
\text { provided a place and a shape } \\
\text { of governance for Pākehā } \\
\text { in Aotearoa }\end{array}$ \\
\hline $\begin{array}{l}\text { Provided the foundation upon } \\
\text { which Māori and Pākehā } \\
\text { would build their } \\
\text { relationship as citizens of } \\
\text { Aotearoa New Zealand }\end{array}$ & $\begin{array}{l}\text { It recognises both the tino } \\
\text { rangatiratanga of Māori } \\
\text { and the kawanatanga of the } \\
\text { Crown in the design and } \\
\text { delivery of the education } \\
\text { system (p. 8) }\end{array}$ & $\begin{array}{l}\text { Te Tiriti o Waitangi provided } \\
\text { a basis for ongoing, peaceful } \\
\text { power-sharing relationships } \\
\text { between the first peoples } \\
\text { and all others who would } \\
\text { come in later years }\end{array}$ \\
\hline $\begin{array}{l}\text { A spirit of partnership and } \\
\text { the acceptance of obligations } \\
\text { for participation and } \\
\text { protection }\end{array}$ & $\begin{array}{l}\text { This will ensure [teachers] } \\
\text { are able to build genuine } \\
\text { partnerships with Māori to } \\
\text { support the identity, language } \\
\text { and culture of Māori children } \\
\text { (p. 8) }\end{array}$ & $\begin{array}{l}\text { A commitment under which } \\
\text { Māori and all other New } \\
\text { Zealanders may live } \\
\text { together in the spirit of } \\
\text { honourable relationships, } \\
\text { with the promise to take the } \\
\text { best possible care of each } \\
\text { other }\end{array}$ \\
\hline $\begin{array}{l}\text { Equitable outcomes for } \\
\text { Māori and ensuring that te } \\
\text { reo Māori not only survives } \\
\text { but thrives }\end{array}$ & $\begin{array}{l}\text { It also includes the } \\
\text { obligation to protect and } \\
\text { actively promote the use of } \\
\text { te reo Māori in all settings, } \\
\text { recognising iwi Māori as } \\
\text { kaitiaki of this taonga (p. } 8 \text { ) }\end{array}$ & $\begin{array}{l}\text { This requires the injustices } \\
\text { caused by colonisation to be } \\
\text { addressed and all New } \\
\text { Zealanders to engage in } \\
\text { creating a positive future that } \\
\text { honours Te Tiriti o } \\
\text { Waitangi }\end{array}$ \\
\hline $\begin{array}{l}\text { Te Tiriti I the Treaty is seen to } \\
\text { be inclusive of all } \\
\text { immigrants to New Zealand, } \\
\text { whose welcome comes in the } \\
\text { context of this partnership }\end{array}$ & $\begin{array}{l}\text { While the biggest range of } \\
\text { ethnicities is found in } \\
\text { Auckland, increasing } \\
\text { diversity has been seen } \\
\text { throughout the country } \\
\text { (p. 11) }\end{array}$ & $\begin{array}{l}\text { New Zealand is an } \\
\text { increasingly multicultural } \\
\text { nation, and Te Tiriti o } \\
\text { Waitangi is inclusive of } \\
\text { today's new settlers }\end{array}$ \\
\hline $\begin{array}{l}\text { Respond to the changing } \\
\text { demographic landscape by } \\
\text { valuing and supporting the } \\
\text { different cultures }\end{array}$ & $\begin{array}{l}\text { The expectations that } \\
\text { different groups bring to early } \\
\text { learning services have } \\
\text { implications for how } \\
\text { services interact with } \\
\text { families and whanau (p. 11) }\end{array}$ & $\begin{array}{l}\text { As with earlier immigrants, } \\
\text { their 'place to stand' comes } \\
\text { with an expectation that they } \\
\text { will live here in a way that } \\
\text { respects the commitments } \\
\text { of Te Tiriti o Waitangi and } \\
\text { the position of Māori as } \\
\text { tangata whenua }\end{array}$ \\
\hline
\end{tabular}

'There is no mention of 'immigrants' or 'migrants' in the Early Learning Action Plan, and no reference to diverse groups in relation to Te Tiriti within the statement on page 8 
Waitangi based discourse juxtaposed alongside the current context of superdiversity. Reference to Te Tiriti o Waitangi is positioned prominently near the beginning of all three documents, signalling its foundational importance. Our Code, Our Standards (Education Council, 2017a) is explicit in the expectation that "As teachers, we are committed to honouring Te Tiriti o Waitangi and we understand this has implications in all of our practice" (p. 4). At the same time, the document recognises that Aotearoa is a "multicultural nation" and explains that "Te Tiriti o Waitangi is inclusive of today's new settlers" (p. 4), although without specifying how this is the case. It states that "Te Tiriti o Waitangi provided a basis for ongoing, peaceful power-sharing relationships between the first peoples and all others who would come in later years" and notes that migrants are expected to "live here in a way that respects the commitments of Te Tiriti o Waitangi and the position of Māori as tangata whenua" (p. 4). This signals the relevance of critical and Indigenous pedagogies of place as foundational within initial teacher education (ITE) in ensuring that these commitments are acknowledged and prioritised by all teachers.

With the increasing numbers of overseas EC teachers recruited via the skill-based migration policy and of international students enrolling in EC teacher education programmes, we question the extent and nature of supports available for teachers and student-teachers who are new to Aotearoa in relation to the Teaching Council's commitments to Te Tiriti. One of the standards in the document states that teachers are expected to "design and plan culturally responsive, evidence-based approaches that reflect the local community and Te Tiriti o Waitangi partnership in New Zealand" (Education Council, 2017a, p. 20). We argue that a deep connection to place and a strong sense of belonging and civic responsibility in promoting and advocating social justice are key to supporting this partnership and advocating for Māori children and families. Hence, we are concerned about how one-year ITE qualifications, in particular, might sufficiently assist those teachers who are relatively new to Aotearoa to interpret and enact their commitment to "affirming Māori learners as tangata whenua and supporting their educational aspirations" (Education Council, 2017a, p. 10).

In the companion document, Examples in Practice, the Council provides examples of "behaviour that does not affirm Māori learners as tangata whenua or actively support their educational success" (Education Council, 2017b, p. 14), such as refusing to learn how to correctly pronounce Māori names including those associated with a child's whakapapa (genealogical connections) "such as their whānau, hapū, iwi, tūpuna, marae, waka or maunga ${ }^{11}$ " or displaying disrespect towards tikanga Māori (values and practices of Māori) (p. 14). Missing from this list of unacceptable practices is acknowledgement that often those who are not committed to inclusion of Tiriti-based commitments may render te reo me te ao Māori (the Māori language

\footnotetext{
${ }^{11}$ Whakapapa are genealogical inter-connections; whānau are extended families; hapū are subtribes; iwi are tribes; tūpuna are ancestors; marae are tribal meeting places; waka are the original voyaging canoes of particular tribal ancestors; maunga are mountains. All of these serve as important markers of identity and connection.
} 
and worldview) invisible in their teaching. It takes time and commitment to master accurate pronunciation of te reo Māori, to understand the historical and political positioning of Te Tiriti, to appreciate and accurately express whakapapa, mātauranga (knowledge) and tikanga, and to demonstrate as teachers our responsibility to support Māori in their role as kaitiaki (guardians) of these taonga (things of value). Considering that currently only $4 \%$ of our population can speak te reo Māori (Statistics New Zealand, 2019), much needs to be done to ensure that student-teachers and teachers who are new to Aotearoa are provided with resources and equitable support to enable them to learn the language and develop a deep connectedness to te ao Māori (the Māori world). New arrivals are unlikely to have similar funds of knowledge (Gonzalez, 2005) to those of local student-teachers who were born and raised in Aotearoa, even though we recognise that within this latter group there is a varied mix of expertise levels. Teacher pre- and in-service education programmes should therefore carefully consider and respond to the contextual backgrounds and learning needs of the full spectrum of local Māori student-teachers, domestic student-teachers with diverse migrant backgrounds, and international student-teachers who may be totally new to the country, by modelling and promoting understandings related to critical and Indigenous pedagogies of place.

The assumption of white/western superiority is a commonality across historical colonisation internationally, underpinning the ongoing racism directed in our country towards those who are not visibly Pākehā (Pihama \& Lee-Morgan, 2018), and it is a responsibility of teacher education programmes to disrupt these entrenched discourses. Whilst our brief application of CDA to the documents has illuminated reliance on such Te Tiriti related discourses as 'partnership' [ostensibly between the Crown and Māori], the subtler implications of recognition of the rights of tangata whenua, whilst discursively acknowledged, are easily dismissed, fading into the shadows in the light of more dominant teaching-related discourses. The desire to 'treat all children the same' first identified by Simon in her 1980s research (1990) remains a powerful assimilative discourse within ECE in Aoteaora (Education Review Office, 2012), one that homogenises cultural differences, ignoring the discourses of inclusion and equity.

\subsection{Commitment Statements: Diversity, Inclusion and Equity}

This section considers three main discourses: diversity, inclusion and equity, identified from the documents reviewed. While the word 'diversity' is typically used in reference to ethnicity, culture, identity and language, the superdiversity approach goes beyond this conventional application to highlight migration-driven diverse social issues (Vertovec, 2007, 2019). Yet, a review of the documents shows that traditional understandings of diversity prevail. Issues that are specific to migrants as highlighted in the superdiversity approach are largely invisible. Table 12.2 highlights a range of key signifiers that illustrate how the discourse of diversity, inclusion and equity are constructed across the three influential documents. 
Table 12.2 Diversity, inclusion and equity: identifying key signifiers

\begin{tabular}{|c|c|c|}
\hline Te Whāriki 2017 & Early learning action plan & Code and standards \\
\hline $\begin{array}{l}\text { Te Whäriki supports children } \\
\text { from all backgrounds to grow } \\
\text { up strong in identity, } \\
\text { language and culture (p. 7) }\end{array}$ & $\begin{array}{l}\text { Respecting the diversity of } \\
\text { the heritage, identity, } \\
\text { language and culture of all } \\
\text { learners and their families } \\
\text { and whanau (p. } 25 \text { ) }\end{array}$ & $\begin{array}{l}\text { Respecting the diversity of } \\
\text { the heritage, language, } \\
\text { identity and cultures of all } \\
\text { learners (p. 10) }\end{array}$ \\
\hline $\begin{array}{l}\text { Able to support the cultural } \\
\text { and linguistic diversity of } \\
\text { all children as part of } \\
\text { promoting an inclusive } \\
\text { environment } \\
\text { (p. 59) }\end{array}$ & $\begin{array}{l}\text { Objective 1: } \\
\text { Children and whānau } \\
\text { experience environments } \\
\text { which promote their } \\
\text { wellbeing and support } \\
\text { identity, language and } \\
\text { culture (p. 6) }\end{array}$ & $\begin{array}{l}\text { Learners can be confident in } \\
\text { their identities, languages, } \\
\text { cultures and abilities (p. 20) }\end{array}$ \\
\hline $\begin{array}{l}\text { Teaching inclusively means } \\
\text { that kaiako (teacher/s) will } \\
\text { work together with families, } \\
\text { whānau and community } \\
\text { (p. 13) }\end{array}$ & $\begin{array}{l}\text { Objective 2: } \\
\text { All children are able to } \\
\text { participate in quality early } \\
\text { learning and have the } \\
\text { support they need to learn } \\
\text { and thrive (p. 6) }\end{array}$ & $\begin{array}{l}\text { Develop a culture that is ... } \\
\text { characterised by respect, } \\
\text { inclusion, empathy, } \\
\text { collaboration and safety } \\
\text { (p. 20) }\end{array}$ \\
\hline $\begin{array}{l}\text { Kaiako promote equitable } \\
\text { opportunities for children } \\
\text { and counter actions or } \\
\text { comments that categorise, } \\
\text { stereotype or exclude } \\
\text { people (p. 40) }\end{array}$ & $\begin{array}{l}\text { The notion of 'equity from } \\
\text { the start' is a key value of } \\
\text { this action plan (p. 13) }\end{array}$ & $\begin{array}{l}\text { Work in the best interests of } \\
\text { learners by being fair and } \\
\text { effectively managing [their] } \\
\text { assumptions and personal } \\
\text { beliefs (p. 18) }\end{array}$ \\
\hline $\begin{array}{l}\text { [Kaiako are] thoughtful and } \\
\text { reflective about what they } \\
\text { do, using evidence, critical } \\
\text { inquiry and problem-solving } \\
\text { to shape their practice (p. 59) }\end{array}$ & $\begin{array}{l}\text { ITE providers will need to } \\
\text { show evidence that graduates } \\
\text { are equipped with the theory } \\
\text { and reflective abilities that } \\
\text { will enable them to practice } \\
\text { in the unfamiliar contexts } \\
\text { where they might ultimately } \\
\text { be employed (p. 25) }\end{array}$ & $\begin{array}{l}\text { Critically examine how } \\
\text { [teachers'] own assumptions } \\
\text { and beliefs, including } \\
\text { cultural beliefs, impact on } \\
\text { practice and the achievement } \\
\text { of learners with different } \\
\text { abilities and needs, } \\
\text { backgrounds, genders, } \\
\text { identities, languages and } \\
\text { cultures (p. 18) }\end{array}$ \\
\hline
\end{tabular}

\subsubsection{Analysis and Discussion: Responding to Superdiversity}

The Code and Standards (Education Council, 2017a) states that teachers in Aotearoa are expected to demonstrate commitment to "respecting the diversity of the heritage, language, identity and cultures of all learners", and to develop a culture that "is characterised by respect, inclusion ..." (p. 20). These can be achieved through creating an environment "where learners can be confident in their identities, languages, cultures and identities" (p. 20). Disrespecting, dismissing, or "making discriminatory or derogatory comments about a learner's heritage, language, identity, beliefs or culture" are illustrated as "examples of not promoting respect" (Education Council, 2017b, p. 13) for these diversities. These four 'types' of diversity, along with the 
notion of inclusive practices are similarly specified in both Te Whäriki 2017 and the Early Learning Action Plan as identified in Table 12.2.

Since more than a quarter of our population was born overseas, and that our nation is now home to more than 200 ethnic groups and 160 different languages (Royal Society of New Zealand, 2013), a respectful and inclusive attitude towards diverse heritages, languages, cultures, and identities is critical to ensuring social justice and cohesion. The multiplicity of Māori, Pākehā and migrant families'specific linguistic and cultural funds of knowledge should all be recognised and included. However, we argue that simply viewing diversity in terms of heritage, identity, language, and culture is inadequate. The context of heightened rates of migration as the main reason for the emergence of these diversities in this country needs specific acknowledgement. The two additional layers of diversity and complexity highlighted in the superdiversity approach: migration statuses and patterns (Vertovec, 2007) are not visible in any of the documents. In fact, while each of the terms 'immigrant' and 'migrant' appears just once in Te Whäriki 2017 and once in the Code and Standards, neither term (including im/migration) is found in the Early Learning Action Plan. The word 'superdiversity' does not appear in any of the documents reviewed.

Without an awareness of the complex migration statuses and patterns of the migrant families they work with, teachers may not understand why some children have to frequently engage in transnational activities which may require them to be absent from EC centres to return to their home countries for an extended period of time. Teachers may assume that transnational migrant families do not take their children's education seriously or that they have no intention of settling in Aotearoa. Differing migration patterns and statuses means that families with migrant backgrounds are extremely heterogeneous and their status may hinder their access to social services. Teachers should indeed "work together with families, whānau and community" (MoE, 2017, p. 13), in order to find out their specific needs and that they have access to appropriate support services related to health, legal matters, language support and so on. In light of the complex layers of diversity and social inequality issues driven by migration, we contend that it is timely to challenge, expand and transform conventional diversity discourse by integrating key ideas from the superdiversity approach (Vertovec, 2007, 2019). This will diversify understandings, address migration-driven inequality issues, and highlight the importance of equitable teaching practices.

The Code and Standards (2017a) also expects teachers to "work in the best interests of learners by being fair and effectively managing [their] assumptions and personal beliefs" and to "critically examine how [their] own assumptions and beliefs, including cultural beliefs, impact on practice and the achievement of learners with different abilities and needs, backgrounds, genders, identities, languages and cultures" (p. 18). The importance of respecting heterogeneity and applying critical pedagogies to respond equitably to individual needs is emphasised in critical multiculturalism (May, 1999; May \& Sleeter, 2010). Chan (2019b) suggested applying both critical multicultural pedagogies and a superdiversity approach to work with diverse migrant families in ECE settings to "promote equitable opportunities for children" (MoE, 2017, p. 13). In order to critically examine one's assumptions and 
beliefs and to advocate for social equity, teachers need to have a disposition of criticality and the ability to engage in self-reflection, which is an expectation highlighted by the Teaching I Education Council (2017a, 2017b). These skills and dispositions, however, are developed through experiencing and socialising in democratic and just education systems and societies. We agree with the statement in the Early Learning Action Plan that "all children should have equitable access to a well-qualified early learning workforce that mirrors the diverse cultures and genders that constitute Aotearoa New Zealand" (MoE, 2019, p. 22). We are concerned that some teachers or student-teachers who are new to Aotearoa may be from places where democracy and critical thinking were not encouraged, and that they may struggle with negotiating their own identities and developing a sense of belonging in their host country. It is therefore important that during their course of study, they experience an equitable learning environment, develop facilities in criticality, and have the opportunity to explore their identities within the context of a Tiriti-based Aotearoa, so that they are well-positioned to advocate for social equity and to support children's increasingly complex identities.

\section{Concluding Considerations}

In a recent article addressing postcolonial considerations for teacher education, Gupta (2020) suggests embracing cultural and pedagogical hybridity, proposing that a "more balanced teacher education curriculum" (p. 52) should be culturally responsive and include diverse global and local knowledges. Such a hybrid approach requires transformative thought and action. The notion of transformation towards a more just society, as promoted in both the superdiversity approach and critical multiculturalism theorising, when applied in the context of EC teacher education in Aotearoa, needs to be grounded in a pedagogical approach that incorporates Te Tiriti o Waitangi commitments to tino rangatiratanga, te reo Māori, taonga katoa, and equal citizenship rights. With the September 2019 announcement that Aotearoa history will from 2020 be taught across the curriculum (Ardern \& Hipkins, 2019) along with the newly introduced Education and Training Bill 2019, which positions the "Treaty of Waitangi at the centre of education" (RNZ, 2019b), we anticipate some interesting and long overdue developments in this regard.

Yet recently arrived migrants, both student-teachers, teachers, children and families, will most likely have had little opportunity to access these understandings. We have suggested that teacher education programmes should include an in-depth focus on critical and Indigenous pedagogies of place and superdiversity related issues in order to ensure that all graduating teachers have a strong foundational understanding of te ao Māori conceptualisations, a critical analysis of the impacts of colonisation and of discourses of white supremacy, along with related transformational pedagogical strategies to employ in their future work as teachers. Also required is equitable support to new 'Kiwi' student-teachers so that, grounded in a sense of their own 
identity, they can competently apply understandings of their responsibilities in relation to the linguistic and cultural specificities of Māori and tangata tiriti children and families. Such support is important for student-teachers to experience and understand how theories are translated into actual practices, so that they are prepared to apply theory-based pedagogies to advocate for families, thereby also bridging the gap between theory and practice (Gupta, 2020). Student-teachers need to experience an equitable teacher education before they can work equitably with diverse children and families.

\section{References}

Aptekar, S. (2019). Super-diversity as a methodological lens: Recentring power and inequality. Ethnic and Racial Studies, 42(1), 53-70. https://doi.org/10.1080/01419870.2017.1406124.

Ardern, J., \& Hipkins, C. (2019). NZ history to be taught in all schools. Retrieved from https:// www.beehive.govt.nz/release/nz-history-be-taught-all-schools.

Blommaert, J. (2013). Citizenship, language, and superdiversity: Towards complexity. Journal of Language, Identity \& Education, 12(3), 193-196. https://doi.org/10.1080/15348458.2013. 797276.

Brawley, S. (1993). 'No "White Policy” in NZ'. Fact and fiction in New Zealand's Asian immigration record, 1946-1978. New Zealand Journal of History, 27(1), 16-36.

Chan, A. (2018). Transnational parenting practices of Chinese immigrant families in New Zealand. Contemporary Issues in Early Childhood, 19(3), 219-230. https://doi.org/10.1177/ 1463949117691204.

Chan, A. (2019a). Te Whāriki: An early childhood curriculum in a superdiverse New Zealand. New Zealand Journal of Educational Studies, 54(2), 245-259. https://doi.org/10.1007/s40841-01900138-z.

Chan, A. (2019b, online first). Superdiversity and critical multicultural pedagogies: Working with migrant families. Policy Futures in Education, 1-14. https://doi.org/10.1177/1478210319873773.

Chan, A., \& Ritchie, J. (2019). Critical pedagogies of place: Some considerations for early childhood care and education in a superdiverse 'bicultural' Aotearoa (New Zealand). International Journal of Critical Pedaogy, 10(1), 51-74. Retrieved from http://libjournal.uncg.edu/ijcp/issue/view/139/ showToc.

Chan, A., \& Spoonley, P. (2017). The politics and construction of identity and childhood: Chinese immigrant families in New Zealand. Global Studies of Childhood, 7(1), 17-28. https://doi.org/ $10.1177 / 2043610617694730$.

Education Council. (2017a). Our code our standards. Wellington: Education Council. Retrieved from https://educationcouncil.org.nz/content/our-code-our-standards.

Education Council. (2017b). The code of professional responsibility: Examples in practice. Retrieved from https://teachingcouncil.nz/sites/default/files/Code\%20Guidance\%20FINAL.pdf.

Education Counts. (2014). Annual ECE census summary report 2014. Wellington: Ministry of Education. Retrieved from https://www.educationcounts.govt.nz/_data/assets/pdf_file/0005/ 184748/Annual-ECE-Census-Summary-Report-2014.pdf.

Education Counts. (2018). Enrolments in early childhood education. Retrieved from https://www. educationcounts.govt.nz/statistics/early-childhood-education.

Education Review Office. (2010). Success for Māori children in early childhood services. Wellington: Education Review Office. Retrieved from https://www.ero.govt.nz/publications/success-formaori-children-in-early-childhood-services/. 
Education Review Office. (2012). Partnership with whānau Māori in early childhood services. Wellington: Education Review Office. Retrieved from http://www.ero.govt.nz/National-Reports/ Partnership-with-Whanau-Maori-in-Early-Childhood-Services-Feb-2012.

Education Review Office. (2013). Working with Te Whäriki. Wellington: Education Review Office. Retrieved from http://www.ero.govt.nz/publications/working-with-te-whariki/.

Freire, P. (1972). Pedagogy of the oppressed. London: Penguin.

Gee, J. P. (2011). An introduction to discourse analysis: Theory and method (3rd ed.). New York: Routledge.

Goldberg, D. T. (2002). The racial states. Malden, MA: Blackwell.

Gonzalez, N. (2005). Beyond culture: The hybridity of funds of knowledge. In N. Gonzalez, L. Moll, \& C. Amanti (Eds.), Funds of knowledge: Theorizing practices in households, communities, and classrooms (pp. 29-46). Mahwah, NJ: Lawrence Erlbaum Associates, Inc., Publishers.

Gupta, A. (2020). Preparing teachers in a pedagogy of third space: A postcolonial approach to contextual and sustainable early childhood teacher education. Journal of Research in Childhood Education, 34(1), 43-58. https://doi.org/10.1080/02568543.2019.1692108.

Hayward, J. (2004). "Flowing from the Treaty's words": The principles of the Treaty of Waitangi. In J. Hayward \& N. R. Wheen (Eds.), The Waitangi Tribunal: Te Roopu Whakamana i te Tiriti o Waitangi (pp. 29-40). Wellington: Bridget Williams Books.

Hickey, B., \& Grieveson, L. (2019). The Dubai of the South Pacific in Reporoa. Retreived from https://www.newsroom.co.nz/2019/12/18/953079/the-dubai-of-the-sth-pacific-in-reporoa.

Immigration New Zealand. (2019). Skill shortage list checker. Retrieved from https://skillshortages. immigration.govt.nz/early-childhood-pre-primary-school-teacher/.

Jørgensen, M., \& Phillips, L. (2002). Discourse analysis as theory and method. London: Sage.

King, M. (2003). The Penguin history of New Zealand. Auckland: Penguin.

Kukutai, T., \& Cormack, D. (2018). Census 2018 and implications for Māori. New Zealand Population Review, 44, 131-151.

Locke, T. (2004). Critical discourse analysis. London: Continuum International Publishing Group.

May, S. (1999). Critical multiculturalism and cultural difference: Avoiding essentialism. In S. May (Ed.), Critical multiculturalism: Rethinking multicultural and antiracist education (pp. 11-41). London: Falmer Press.

May, S., \& Sleeter, C. E. (2010). Introduction. Critical multiculturalism: Theory and praxis. In S. May \& C. E. Sleeter (Eds.), Critical multiculturalism: Theory and praxis (pp. 1-16). New York: Routledge.

Ministry of Education. (2017). Te Whāriki. He whāriki mātauranga mō ngā mokopuna o Aotearoa. Early childhood curriculum. Retrieved from https://www.education.govt.nz/assets/Documents/ Early-Childhood/Te-Whariki-Early-Childhood-Curriculum-ENG-Web.pdf.

Ministry of Education. (2019). He taonga te tamaiti. Every child a taonga. Early learning action plan 2019-2029. Retrieved from https://conversation-space.s3-ap-southeast-2.amazonaws.com/ SES_0342_ELS_10YP_Final+Report_Web.pdf.

Ministry of Social Development. (2016). The social report. Retrieved from http://socialreport.msd. govt.nz/.

New Zealand Parliament. (1987). Maori Language Act 1987. Retrieved from http://www.legislation. govt.nz/act/public/1987/0176/latest/whole.html.

Orange, C. (1988). The Treaty of Waitangi - A historical overview. Wellington: New Zealand Planning Council.

Orange, C. (2017). The Treaty of Waitangi | Te Tiriti o Waitangi 1840. Wellington: Archives New Zealand I Te Rua Mahara o te Kāwanatanga; National Library of New Zealand I Te Puna Mātauranga Aotearoa; Bridget Williams Books.

Penetito, W. (2002). Research and context for a theory of Maori schooling. McGill Journal of Education, 37, 89-110.

Penetito, W. (2009). Place-based education: Catering for curriculum, culture and community. New Zealand Annual Review of Education, 18, 5-29. 
Perumal, J. C. (2015). Critical pedagogies of place: Educators' personal and professional experiences of social (in)justice. Teaching and Teacher Education, 45, 25-32. https://doi.org/10.1016/ j.tate.2014.09.004.

Pihama, L., \& Lee-Morgan, J. (2018). Colonization, education, and Indigenous peoples. In E. A. McKinley \& L. T. Smith (Eds.), Handbook of Indigenous Education (pp. 1-9). Singapore: Springer Nature.

Radio New Zealand. (2019a). Increase in suicides for Māori and teens, latest stats show. Retrieved from https://www.rnz.co.nz/news/te-manu-korihi/397516/increase-in-suicidesfor-maori-and-teens-latest-stats-show.

Radio New Zealand. (2019b). Education Minister Chris Hipkins details changes in big new bill. Retrieved from https://www.rnz.co.nz/news/national/404702/education-minister-chris-hipkinsdetails-changes-in-big-new-bill.

Ritchie, J. (2002). "It's becoming part of their knowing": A study of bicultural development in an early childhood teacher education setting in Aotearoa/New Zealand. (Ph.D. thesis). University of Waikato, Hamilton, NZ.

Royal Society of New Zealand. (2013). Languages in Aotearoa New Zealand. Retrieved from https://royalsociety.org.nz/what-we-do/our-expert-advice/all-expert-advice-papers/languagesin-aotearoa-new-zealand/.

Salmond, A. (1991). Two worlds: First meetings between Māori and Europeans, 1642-1772. Auckland: Viking.

Simon, J. (1990). 'Good intentions, but...' In R. Steele (Ed.), Whakamana Tangata. A beginner's guide to cultural identity (pp. 44-48). Wellington: Ministry of Education.

Spoonley, P. (2015). New diversity, old anxieties in New Zealand: The complex identity politics and engagement of a settler society. Ethnic and Racial Studies, 38(4), 650-661. https://doi.org/ 10.1080/01419870.2015.980292.

Spoonley, P. (2017). Renegotiating citizenship: Indigeneity and superdiversity in contemporary Aotearoa/New Zealand. In J. Mann (Ed.), Citizenship in transnational perspective. Politics of citizenship and migration (pp. 209-222). Cham: Palgrave Macmillan.

Spoonley, P., \& Bedford, R. (2012). Welcome to our world? Immigration and the reshaping of New Zealand. Auckland: Dunmore Publishing Ltd.

Statistics New Zealand. (2019). New Zealand's population reflects growing diversity. Retrieved from https://www.stats.govt.nz/news/new-zealands-population-reflects-growing-diversity.

Stockholm Resilience Centre. (2019). Time for an emergency response. Retrieved from https:// stockholmresilience.org/research/research-news/2019-11-27-time-for-an-emergency-response. html.

Tolley, P. (2019). Forever home - Why immigrants chose New Zealand. Retrieved from https://www. rnz.co.nz/national/programmes/insight/audio/2018722176/forever-home-why-immigrantschose-new-zealand.

Turia, T. (2016). A Māori political leader's perspective. Te Manutukutuku, 69, 36. Retrieved from https://www.waitangitribunal.govt.nz/assets/Documents/Publications/WT-69Te-Manutukutuku.pdf.

United Nations. (2019). UN report: Nature's dangerous decline 'unprecedented'; species extinction rates 'accelerating'. Retrieved from https://www.un.org/sustainabledevelopment/blog/2019/05/ nature-decline-unprecedented-report/.

Vertovec, S. (2007). Super-diversity and its implications. Ethnic and Racial Studies, 30(6), 1024 1054. https://doi.org/10.1080/01419870701599465.

Vertovec, S. (2019). Talking around super-diversity. Ethnic and Racial Studies, 42(1), 125-139. https://doi.org/10.1080/01419870.2017.1406128.

Walker, R. (2004). Ka Whawhai Tonu Matou. Struggle without end (revised ed.). Auckland: Penguin.

Williams, L., Bunda, T., Claxton, N., \& MacKinnon, I. (2018). A global de-colonial praxis of sustainability - undoing epistemic violences between Indigenous peoples and those no longer Indigenous to place. The Australian Journal of Indigenous Education, 47(1), 41-53. https://doi. org/10.1017/jie.2017.1025. 
Dr. Angel Chan is a senior lecturer at the Faculty of Education and Social Work, University of Auckland, Aotearoa New Zealand. Her teaching and research aim at promoting social justice and cohesion, covering areas such as early childhood education, the politics of identity, transnational parenting, critical multicultural education, and superdiversity in education settings.

Dr. Jenny Ritchie is an Associate Professor in Te Puna Akopai, the School of Education, at Te Herenga Waka Victoria University of Wellington, Aotearoa New Zealand. Her research and teaching focus on social, cultural and ecological justice in early childhood care and education. 